\title{
Correction to: A national evaluation of the Irish public health counselling in primary care service- examination of initial effectiveness data
}

\author{
Charles Brand ${ }^{1,2^{*}}$, Fiona Ward ${ }^{3}$, Niamh MacDonagh ${ }^{4}$, Sharon Cunningham ${ }^{5}$ and Ladislav Timulak ${ }^{1}$
}

\section{Correction to: BMC Psychiatry 21, 227 (2021)}

https://doi.org/10.1186/s12888-021-03226-x

Following the publication of the original article [1], the authors identified an error in the affiliation of Dr. Ladislav Timulak.

The correct affiliation is given below:

1 School of Psychology, Trinity College, Dublin 2, Ireland.

\footnotetext{
Author details

${ }^{1}$ School of Psychology, Trinity College, Dublin 2, Ireland. ${ }^{2}$ Health Service Executive, Counselling in Primary Care National Evaluation, 19 Upper Ormond Quay, Dublin 2, Ireland. ${ }^{3}$ Health Service Executive, 34 Brew's Hill, Navan, Co, Meath, Ireland. ${ }^{4}$ Health Service Executive, Primary Care Centre, 1 st Floor Junction House, Airton Rd., Tallagh, Co, Dublin, Ireland. ${ }^{5}$ Health Service Executive, Unit 8A Brulington Business Park, Srah Avenue, Tullamore, Co, Offaly, Ireland.
}

Published online: 01 June 2021

\section{Reference}

1. Brand C, et al. A national evaluation of the lrish public health counselling in primary care service- examination of initial effectiveness data. BMC Psychiatry. 2021;21:227. https://doi.org/10.1186/s12888-021-03226-x.

The original article can be found online at https://doi.org/10.1186/s12888021-03226-x

*Correspondence: brandc@tcd.ie

${ }^{1}$ School of Psychology, Trinity College, Dublin 2, Ireland

${ }^{2}$ Health Service Executive, Counselling in Primary Care National Evaluation, 19

Upper Ormond Quay, Dublin 2, Ireland

C C The Author(s). 2021 Open Access This article is licensed under a Creative Commons Attribution 4.0 International License, which permits use, sharing, adaptation, distribution and reproduction in any medium or format, as long as you give appropriate credit to the original author(s) and the source, provide a link to the Creative Commons licence, and indicate if changes were made. The images or other third party material in this article are included in the article's Creative Commons licence, unless indicated otherwise in a credit line to the material. If material is not included in the article's Creative Commons licence and your intended use is not permitted by statutory regulation or exceeds the permitted use, you will need to obtain permission directly from the copyright holder. To view a copy of this licence, visit http://creativecommons.org/licenses/by/4.0/ The Creative Commons Public Domain Dedication waiver (http://creativecommons.org/publicdomain/zero/1.0/) applies to the data made available in this article, unless otherwise stated in a credit line to the data. 